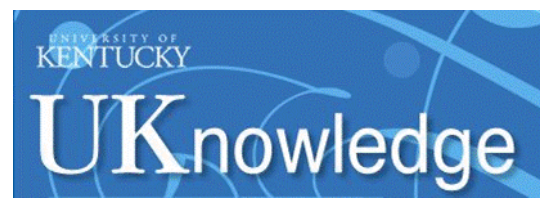

University of Kentucky

UKnowledge

$11-2000$

\title{
Mortality of Escherichia coli 0157:H7 in Two Soils with Different Physical and Chemical Properties
}

\author{
D. N. Mubiru \\ University of Kentucky \\ Mark S. Coyne \\ University of Kentucky, mark.coyne@uky.edu \\ John H. Grove \\ University of Kentucky, jgrove@uky.edu
}

Follow this and additional works at: https://uknowledge.uky.edu/pss_facpub

Part of the Environmental Microbiology and Microbial Ecology Commons, and the Plant Sciences

Commons

Right click to open a feedback form in a new tab to let us know how this document benefits you.

\section{Repository Citation}

Mubiru, D. N.; Coyne, Mark S.; and Grove, John H., "Mortality of Escherichia coli 0157:H7 in Two Soils with Different Physical and Chemical Properties" (2000). Plant and Soil Sciences Faculty Publications. 7.

https://uknowledge.uky.edu/pss_facpub/7

This Article is brought to you for free and open access by the Plant and Soil Sciences at UKnowledge. It has been accepted for inclusion in Plant and Soil Sciences Faculty Publications by an authorized administrator of UKnowledge. For more information, please contact UKnowledge@lsv.uky.edu. 


\section{Mortality of Escherichia coli 0157:H7 in Two Soils with Different Physical and Chemical Properties}

Digital Object Identifier (DOI)

http://dx.doi.org/10.2134/jeq2000.00472425002900060012x

\section{Notes/Citation Information}

Published in Journal of Environmental Quality, v. 29, no. 6, p. 1821-1825.

The copyright holder has granted the permission for posting the article here. 


\title{
Ecological Risk Assessment
}

\section{Mortality of Escherichia coli O157:H7 in Two Soils with Different Physical and Chemical Properties}

\author{
D. N. Mubiru, M. S. Coyne,* and J. H. Grove
}

\begin{abstract}
Wild and domesticated animals can harbor a pathogenic Escherichia coli strain designated as 0157:H7. Potential health problems could occur if strain 0157:H7 is a more robust survivor in defecated waste than commonly used indicator bacteria. A laboratory study was conducted to assess $E$. coli $0157: H 7$ survival relative to a nonpathogenic $E$. coli strain in two soils with different physical and chemical characteristics. Bacteria in the inoculated soils were enumerated on a weekly basis for $8 \mathrm{wk}$ using a most probable number (MPN) technique. First-order decay models were used to describe bacteria mortality in the soils. Decay series were described slightly better by a two-stage function than by a single-stage function. Strain 0157:H7 exhibited similar mortality patterns to the nonpathogenic $E$. coli in the same soil environment. Both $E$. coli strains had greater mortality rates in Pope silt loam (coarse-loamy, mixed, active, mesic Fluventic Dystrudept) than Zanesville silt loam (fine-silty, mixed, active, mesic Oxyaquic Fragiudalf). Differences in available soil water probably were the overriding factor in $E$. coli survival. Escherichia coli 0157:H7 survival could be modeled in the same way as nonpathogenic $E$. coli and appears to have a slightly higher mortality rate.
\end{abstract}

$\mathrm{O}$ NE of the main concerns with pathogenic enteric microorganisms is their survival in soil after manure or biosolids deposition. Any soil condition that favors extended growth and survival of enteric pathogens presents a health hazard because it increases the likelihood of disease transmission. Consequently, it is important that soil conditions influencing the survival of these microorganisms be determined. Several studies on the survival of enteric microorganisms outside of the human or animal gastrointestinal tract indicate that the mortality rate is initially very high (Crane et al., 1980). Two to three months is sufficient in most cases to reduce pathogens to negligible numbers once they have been applied to soil (Zhai et al., 1995). However, survival for as long as $5 \mathrm{yr}$ has been documented (Gerba and Bitton, 1984; Rudolfs et al., 1950).

Survival times among different bacteria and even different bacterial strains vary greatly and it is generally expensive and time consuming to test for enteric pathogens individually. Nonpathogenic indicator bacteria of enteric origin, which are easier and less expensive to monitor, are often used to model the survival of pathogens in soil and water. Current methods to rapidly detect fecal indicator bacteria use defined substrate technology

Department of Agronomy, Univ. of Kentucky, Lexington, KY 405460091. Contribution (Paper no. 00-06-33) of the Kentucky Agric. Exp. Stn., published with the approval of the director. Received 17 Feb. 2000. *Corresponding author (mscoyn00@pop.uky.edu).

Published in J. Environ. Qual. 29:1821-1825 (2000). to identify specific organisms (Covert et al., 1992). In particular, the capacity of fecal coliforms (i.e., Escherichia coli) to hydrolyze the fluorescent indicator compound MUG (4-methylumbelliferyl $\beta$-D-glucuronide) has been exploited to provide presumptive evidence for fecal contamination of water (Rice et al., 1990, 1991). Some fecal coliforms are unable to hydrolyze MUG, which means they give false negative responses to this quick test (Coyne and Shuler, 1994).

Among the E. coli strains demonstrating a MUGnegative response is the virulent enterohemorrhagic (EHEC) pathogen designated as O157:H7, which has been found in asymptomatic cattle, sheep, swine, deer, dogs, horses, and fowl (USDA, 1997). This is the predominant EHEC strain in the USA and it has caused several notable disease outbreaks due to contamination of drinking water, ground beef, and swimming pools.

The consequences of long-term pathogenic fecal coliform survival in soil are serious, particularly if those strains are more robust than nonpathogenic indicator bacteria and constitute an increasing fraction of the soil fecal coliform population with time. The detection and survival of $0157: \mathrm{H} 7$ has been examined in waste, food, and water (Hovde et al., 1999; Pyle et al., 1999), but comparative studies relating the survival of $E$. coli strain O157:H7 in soil to typical nonpathogenic indicator fecal coliforms are lacking. This study was therefore conducted to compare the mortality rate of $E$. coli $\mathrm{O} 157: \mathrm{H} 7$ with that of a nonpathogenic $E$. coli strain in two typical Kentucky soils with different physical and chemical characteristics.

\section{MATERIALS AND METHODS}

\section{Soil Analysis and Experiment Design}

Two soils were selected for the study, Pope silt loam and Zanesville silt loam, that varied appreciably in physical and chemical properties (Table 1). The soils were analyzed for particle size and other common soil properties (e.g., exchangeable bases, cation exchange capacity [CEC], extractable $\mathrm{N}$, and soil organic matter) using standard methods of soil analysis (Soil Survey Staff, 1992). Soil pH was determined in a 1:1 soil to deionized water slurry. Soil water potential was determined by the psychrometer thermocouple method using a pressure plate (Rawlins and Campbell, 1986). The experiment design was a two by two factorial with two types of soil and two strains of bacteria. Experimental units consisted of 96 polyethylene bags.

Abbreviations: EHEC, enterohemorrhagic Escherichia coli; MUG, 4methylumbelliferyl $\beta$-D-glucuronide. 
Table 1. Soil physical, chemical, and biological characteristics prior to $E$. coli addition.

\begin{tabular}{lcc}
\hline Characteristic & Pope silt loam & Zanesville silt loam \\
\hline Texture (g/kg) & & \\
Clay & 250 & 120 \\
Silt & 590 & 670 \\
Sand & 160 & 210 \\
pH & 5.6 & 5.5 \\
Mehlich III extractable (mg/kg) & 1380 & 980 \\
Ca & 155 & 74 \\
Mg & 85 & 44 \\
K & 21 & 14 \\
P & 13 & 2 \\
Zn & & \\
Soil organic & 28.0 & 17.3 \\
matter $(\mathrm{g} / \mathrm{kg})$ & 1510 & 1000 \\
Total N (mg/kg) & nd $\dagger$ & nd \\
Total coliforms & & \\
\hline
\end{tabular}

$\dagger$ nd $=$ not detectable.

\section{Inoculation Method}

Escherichia coli strain 0157:H7 and a nonpathogenic E. coli isolate (American Type Culture Collection [ATCC] 27662) were obtained from the Food Science Department at the University of Kentucky and prepared by growing cultures overnight at $35^{\circ} \mathrm{C}$ in a nutrient broth (EC medium, Difco, Detroit, MI). Cells were harvested by centrifugation at 5000 $\mathrm{rpm}$ in an SS-34 rotor (Sorvall/Heraeus, Newton, CT) and washed in physiological saline $(0.15 \mathrm{M} \mathrm{NaCl})$ three times, each time centrifuging at $5000 \mathrm{rpm}$ in an SS-34 rotor for $15 \mathrm{~min}$. The washed cells were resuspended in $90 \mathrm{~mL}$ of sterile phosphate buffer (Fisher, Cincinnati, $\mathrm{OH}$ ). The resuspended cells were brought to a final volume of $300 \mathrm{~mL}$ by adding deionized water. Bacteria concentrations in the suspensions were determined by standard spread plate method. Four dilutions and four replicates of each sample were plated on plate count agar. Colonies were counted after incubation at $35^{\circ} \mathrm{C}$ for $24 \mathrm{~h}$. Nonsterile soil samples weighing $1.5 \mathrm{~kg}$ that had been airdried and crushed to pass a $2-\mathrm{mm}$ sieve were mixed with the $E$. coli suspensions to produce soils with $20 \%$ gravimetric water content. Approximately $62 \mathrm{~g}$ of the inoculated soils were placed in polyethylene bags that were sealed to maintain soil moisture and incubated at $25^{\circ} \mathrm{C}$.

\section{Escherichia coli Enumeration}

Escherichia coli were enumerated from three replicate polyethylene bags every week for 8 wk using a most probable number (MPN) method (Woomer, 1994). Prior to inoculation with bacteria, the total coliform populations in each soil were negligible (Table 1). Immediately after inoculation the soils were assayed to determine the $E$. coli population at zero time. Ten grams of soil from each sample were serially diluted by 10-fold steps into a sterile phosphate buffer (Woomer, 1994). Culture tubes containing a defined substrate medium (COLITAG) (Chang et al., 1989) with ONPG ( $o$-nitrophenyl- $\beta-D$ galactopyranoside) to detect $\beta$-galactosidase activity by total coliforms were inoculated from each soil after serial dilution. Five replicate tubes were used for each dilution. Most probable number was determined after incubation at $35^{\circ} \mathrm{C}$ for $48 \mathrm{~h}$.

\section{Data Analysis}

The data are reported as $\log _{10}$ values. Data were analyzed as a randomized block (soil types = blocks) split-plot over time using the PROC GLM procedure of SAS (SAS Institute, 1985). Differences between soil types and bacteria strains were evaluated using the soil type $\times$ bacteria strain mean square in the denominator of the $F$ test.

First-order kinetics were assumed to follow the equation:

$$
-d(A) / d t=k A
$$

where $A=$ the parameter under investigation (population), $k=$ the specific mortality rate constant, and $t=$ time. Upon integrating this differential form, the following linear equation was generated:

$$
\log _{10} A=-k t+\text { constant }
$$

A simple regression was performed on this linear transform to calculate the best fit for the data. The coefficient of determination $\left(r^{2}\right)$ is a measure of the proportion of total sum of squares attributed to the independent variable and gives an idea of how well the model fits the data (Crane et al., 1980).

\section{RESULTS}

The two soils were silt loams, but Pope soil had twice as much clay as the Zanesville soil (Table 1). Pope soil

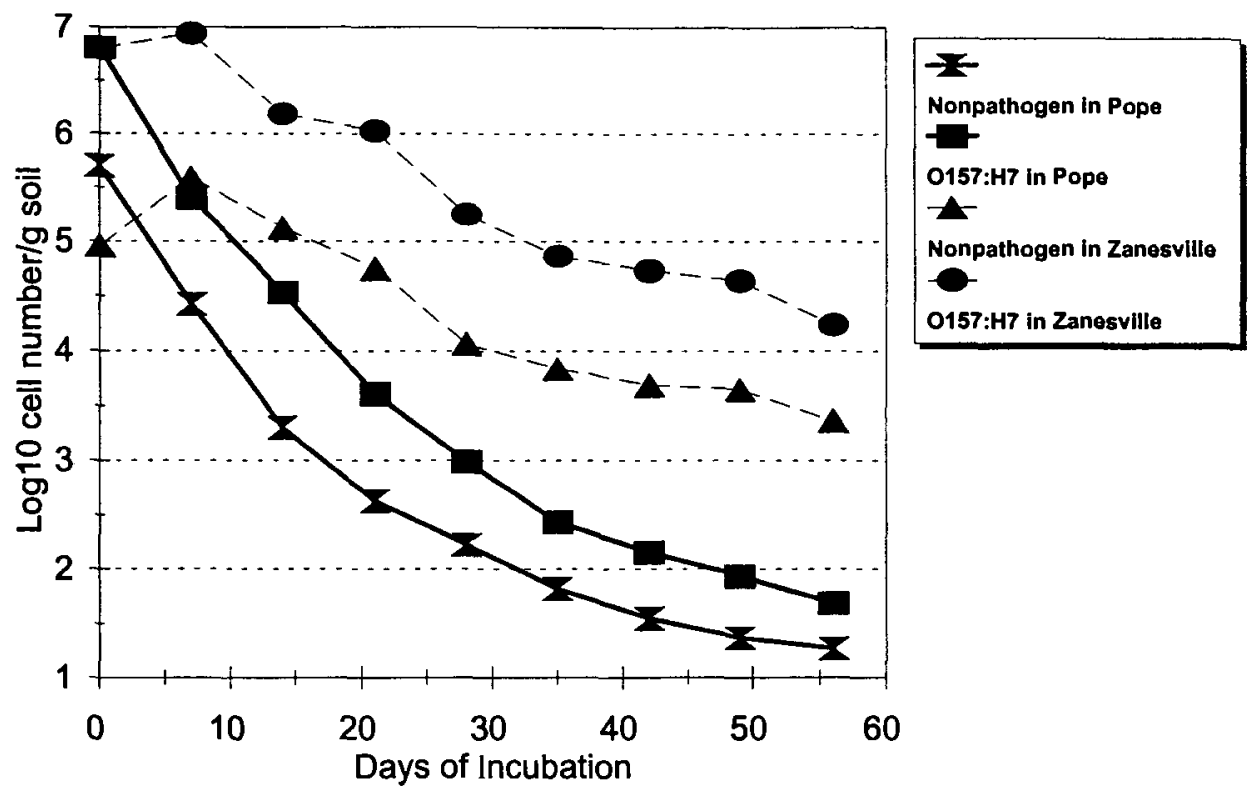

Fig. 1. Mortality of $E$. coli strains in two soils with different physical and chemical characteristics. 
also generally had more exchangeable bases, soil organic matter, and nitrogen. Figure 1 shows the $\log _{10}$ cell number as a function of days of incubation. Both strains appeared to have similar survival patterns in the individual soils. However, there were marked differences in the survival pattern between soils. Both strains initially regrew in the Zanesville soil, while die-off in Pope soil was apparent in the first week.

The analysis of variance for $\log _{10}$ cell numbers per gram of soil is presented in Table 2. Interactions between soil type and bacteria strain, soil type and days of incubation, and bacteria and days of incubation, depicted in Fig. 1, were all highly significant (Table 2). Consequently, even though overall differences between soil types (Pope vs. Zanesville) were significant (Table $2, p \leq 0.1$ ), differences were not independent of days of incubation (Fig. 1). No significant difference was found between bacteria strains at $p \leq 0.1$.

A first-order decay model (Eq. [2]) was used to describe the $E$. coli mortality in the soils. Decay series were described better by a two-stage first-order function than a single-stage first-order function (Table 3 ). However, the overall regression coefficients $\left(r^{2}\right)$ from a single-stage first-order function were relatively high $(0.89$ to 0.93 ). Both strains had greater mortality rates in Pope soil than Zanesville soil. The overall mortality rate constant for O157:H7 in Pope was $-0.17 \mathrm{~d}^{-1}$ and that of the nonvirulent $E$. coli strain was $-0.14 \mathrm{~d}^{-1}$ (Table 3). In Zanesville soil, the mortality rate constant for O157:H7 was $-0.11 \mathrm{~d}^{-1}$ and that of the nonvirulent strain was $-0.09 \mathrm{~d}^{-1}$.

When modeled as a two-stage function, the initial mortality rates of the $E$. coli strains were 36 to $88 \%$ higher (Table 3 ). The mortality rate constants derived from a two-stage first-order function indicated that the initial mortality rates were a function of soil type whereas the subsequent mortality rates were a function of the E. coli strain. That notwithstanding, the initial mortality rate constants $\left(-0.15\right.$ to $\left.-0.25 \mathrm{~d}^{-1}\right)$ compared with the subsequent mortality rate constants $(-0.05$ to $-0.08 \mathrm{~d}^{-1}$ ) indicated that the proportional effect on mortality ascribed to the soil type was by far greater than that due to the $E$. coli strain.

Although the Pope soil had higher exchangeable bases, total $\mathrm{N}$, and organic matter content than the Zanesville soil (properties that have been associated with prolonged bacterial survival in soil), the Zanesville soil nevertheless had lower mortality rates and promoted $E$. coli growth. To help explain this unexpected trend in $E$. coli mortality, we determined the matric
Table 2. Analysis of variance for $\log _{10}$ cell number/g soil in Pope and Zanesville silt loams inoculated with two bacteria strains.

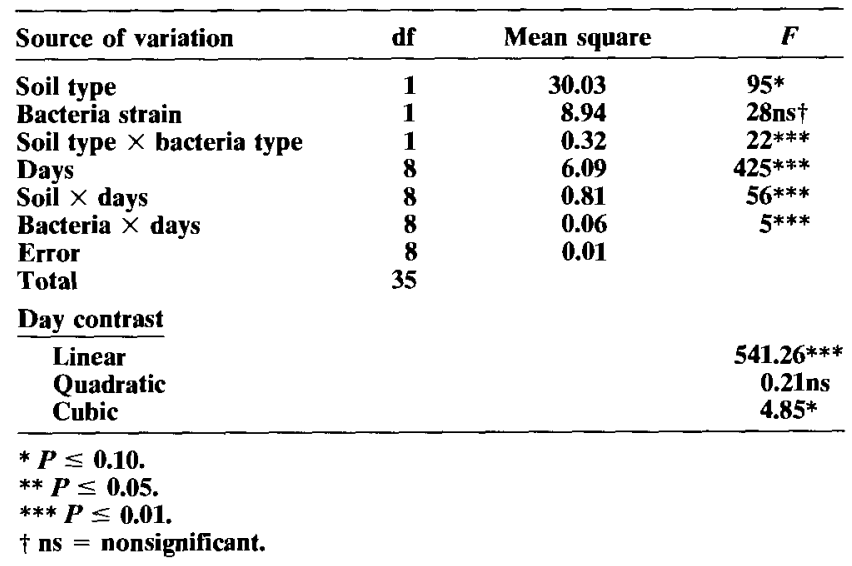

potential of the soils (Fig. 2). Given the pronounced difference in clay content between the two soils, we surmised that matric potential in the individual soils was a significant factor affecting survival. For any given water content, the matric potential of the Pope soil was lower than that of the Zanesville soil. At $20 \%$ gravimetric water content, the matric potential in the Pope soil was $43 \%$ more negative than the Zanesville soil.

\section{DISCUSSION}

There are several instances where enteric bacteria regrowth has been observed in soil. Cuthbert et al. (1950) observed fecal coliform regrowth in neutral calciferous soils and acid soils treated with calcium carbonate. They attributed this phenomenon to greater nutrient availability and more hospitable conditions encountered near physiological $\mathrm{pH}$. Van Donsel et al. (1967) observed a similar phenomenon for fecal coliforms applied to field plots, which they attributed to the prevailing weather conditions, especially changes in soil moisture and temperature. Howell et al. (1996) observed that fecal coliforms and fecal streptococci increased for the first $3 \mathrm{~d}$ after dairy (Bos taurus) manure was added to sand, silt, or clay sediment at 25 or $35^{\circ} \mathrm{C}$. Likewise, Stoddard et al. (1998) observed that net fecal coliform mortality was delayed after spring application of dairy manure to a Maury silt loam (fine, mixed, semiactive, mesic Typic Paleudalf), though not after fall application.

Some important variables documented to control the survival of enteric organisms following application to

Table 3. Mortality rate constants for $E$. coli strains in Pope and Zanesville silt loams.

\begin{tabular}{|c|c|c|c|c|c|c|c|}
\hline \multirow[b]{3}{*}{ Soil } & \multirow[b]{3}{*}{ Strain } & \multicolumn{6}{|c|}{ Mortality rate constants } \\
\hline & & \multicolumn{2}{|c|}{ Single first-order fuuction } & \multicolumn{4}{|c|}{ Two-stage first-order function } \\
\hline & & $r^{2}$ & $k$ & $r_{1}^{2}$ & $k_{1}$ & $r_{2}^{2}$ & $k_{2}$ \\
\hline & & & $d^{-1}$ & & $d^{-1}$ & & $\overline{d^{-1}}$ \\
\hline Pope & $\begin{array}{l}\# 27662 \dagger \\
0157 \cdot H 7\end{array}$ & 0.89 & $\begin{array}{l}-0.14 \\
-017\end{array}$ & 0.94 & $\begin{array}{l}-0.21 \\
-0.25\end{array}$ & 0.96 & $\begin{array}{l}-0.06 \\
-0.08\end{array}$ \\
\hline Zanesville & $\begin{array}{c}\text { \#27662 } \\
\text { O157:H7 }\end{array}$ & $\begin{array}{l}0.90 \\
0.93\end{array}$ & $\begin{array}{l}-0.09 \\
-0.11\end{array}$ & $\begin{array}{l}0.97 \\
0.87\end{array}$ & $\begin{array}{l}-0.17 \\
-0.15\end{array}$ & 0.95 & $\begin{array}{l}-0.05 \\
-0.07\end{array}$ \\
\hline
\end{tabular}

$\dagger$ American Type Culture Collection (ATCC) Strain no. 27662. 


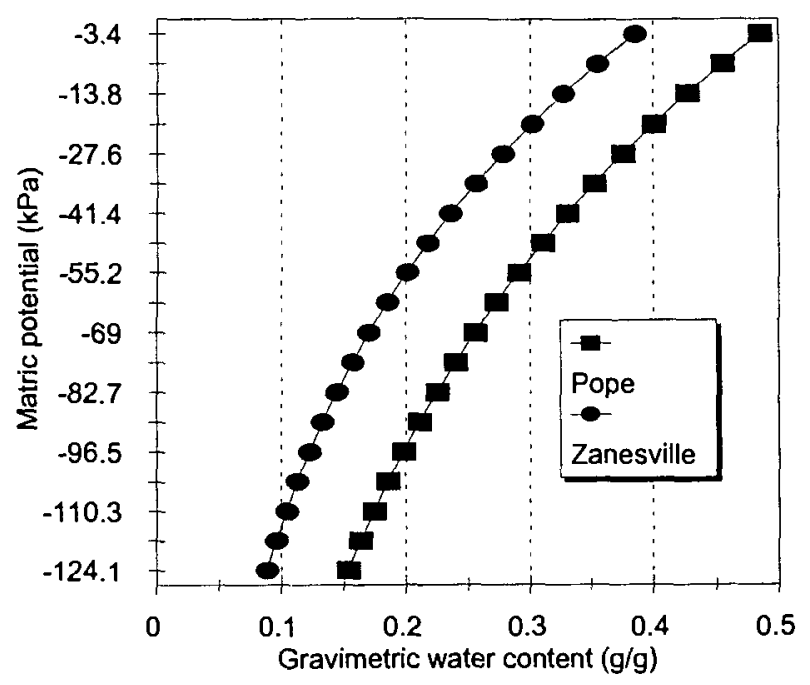

Fig. 2. Matric potential as a function of gravimetric water content in Pope and Zanesville silt loams with different physical and chemical characteristics.

soil include the physical and chemical properties of the soil, atmospheric conditions, and biological interactions with other soil organisms (Crane et al., 1980; Gerba and Bitton, 1984; Morrison and Martin, 1977). Fine soil particles have also been shown to increase E. coli survival. Soils of fine texture and high organic matter content have been observed to support microbial populations three times larger than coarse textured soils (Gerba and Bitton, 1984), a factor also attributed to higher nutrient concentrations (Tate, 1978). Howell et al. (1996) demonstrated that fecal bacteria survival was significantly better in the presence of saturated clays compared with silt- or sand-sized particles.

Among the physical and chemical properties in soil, soil water content is a major factor determining fecal bacteria survival. Greater survival is associated with moist soils and periods of high rainfall (Beard, 1940; Reddy et al., 1981; Young and Greenfield, 1923). Tate (1978) observed that fecal coliform survival was greatly extended in organic soils compared with mineral soils, a factor he attributed to a high water holding capacity and nutrient concentrations in these soils.

In contrast to the previously cited studies in which high organic matter, soil nutrients, and clay content promoted $E$. coli survival, our study suggested that differences in available water were, apparently, the overriding factor in $E$. coli survival in the two soils we examined. We ascribed the lower matric potential in the Pope soil, for the same water content, to the higher clay content $(250 \mathrm{~g} / \mathrm{kg})$ in the Pope soil compared with the Zanesville soil $(120 \mathrm{~g} / \mathrm{kg})$. The negative effects of low matric potentials on bacterial growth and survival in soil are well documented (Harris, 1980; Griffin, 1980), particularly for gram negative bacteria such as the fecal coliform strains used in this study. The more negative matric potential in the Pope soil probably accelerated mortality because the $E$. coli in this soil had to overcome a higher potential to meet their water requirements. On the other hand, because of the less negative matric potential in the Zanesville soil, the $E$. coli probably experienced less water stress, thus the regrowth in the first week and the lower mortality rates observed during the subsequent weeks of the experiment.

Soil matric potential could influence E. coli survival patterns in soil, particularly in soils for which water is limiting. However, it is plausible that at reduced microbial concentrations, as occurred during the progress of the experiment, there was less competition among the microbes, therefore, factors external to the $E$. coli had progressively less effect on their survival patterns than did intrinsic cell properties. Regardless of this possibility, the models we used to explore mortality of the pathogenic and nonpathogenic strains in soil showed no significant differences within the same soil type.

These results also reflect only the biochemically active cells. Differences between the pathogenic and nonpathogenic strains in the rate at which viable but biochemically inert cells form could be a consideration. In addition, because our study was narrowly focused on only two soils and because the E. coli were removed from the milieu of fecal deposits, it would be worth investigating further a greater variety of soil types, physical and chemical properties, and fresh and aged deposits.

\section{CONCLUSIONS}

Although it is generally accepted that indicator microorganisms of enteric origin are affected in the same manner as pathogens in soil, in most studies it has been established that they survive longer than pathogens. In this study, the nonpathogenic $E$. coli strain consistently had lower mortality rate constants and therefore survived in higher numbers slightly longer than the pathogen $0157: \mathrm{H} 7$. However, the differences were not statistically significant. Escherichia coli $0157: \mathrm{H} 7$ exhibited similar survival patterns to the nonpathogenic strain in the same soil. The data suggest that because $0157: \mathrm{H} 7$ had similar mortality rates to a nonpathogenic $E$. coli strain, it is unlikely to predominate in soil environments and increase the risk of false negative indications of fecal contamination. Rapid defined substrate tests for E. coli, and conservative preventive measures after their detection, should be adequate to minimize health risks due to fecal contamination of soil and ground water, even though some potential E. coli strains, such as O157:H7, elude detection by these methods because of their variable MUG response.

Although the overall regression coefficients from a single-stage first-order function were relatively high, the rate constants derived from the first-order kinetics appeared to underestimate the longevity of $E$. coli in the two soils tested. As a matter of public health, a more conservative approach is to use a two-stage first-order function, which seems to be a better predictor of the survival of $E$. coli in soil than a single-stage firstorder function.

\section{ACKNOWLEDGMENTS}

We would like to acknowledge the technical assistance of Abigail Villalba in the culturing and enumeration of fecal 
coliforms. Mr. Mubiru is supported by a grant from the Kentucky Senate Bill 271 Program.

\section{REFERENCES}

Beard, P.J. 1940. Longevity of Eberthella typosus in various soils. Am. J. Publ. Health 30:1077-1082.

Chang, G.W., J. Brill, and R. Lum. 1989. Proportion of $\beta$-D-glucuronidase negative Escherichia coll in human fecal samples. Appl. Environ. Microbiol. 55:335-339.

Covert, T.C., E.W. Rice, S.A. Johnson, D. Berman, C.H. Johnson, and P.J. Mason. 1992. Comparing defined-substrate coliform tests for the detection of Escherichia coli in water. J. Am. Water Works Assoc. 84:98-104.

Coyne, M.S., and J.C. Shuler. 1994. Frequency of MUG negative Escherichia coli in Kentucky groundwater supplies. J. Environ. Qual. 23:126-129.

Crane, S.R., P.W. Westerman, and M.R. Overcash. 1980. Die-off of fecal indicator organisms following land application of poultry manure. J. Environ. Qual. 9:531-537.

Cuthbert, W.A., J.J. Panes, and E.C. Hill. 1950. Survival of Bacterium coli type I and Streptococcus faecalis in soil. J. Appl. Bacteriol. 18:408-414.

Gerba, C.P., and G. Bitton. 1984. Microbial pollutants: Their survival and transport pattern to groundwater. p. 65-88. In G. Bitton and C.P. Gerba (ed.) Groundwater pollution microbiology. John Wiley \& Sons, New York.

Griffin, D.M. 1980. Water potential as a selective factor in the microbial ecology of soils. p. 141-151. In L.F. Elliot et al. (ed.) Water potential relations in soil microbiology. SSSA Spec. Publ. 9. SSSA, Madison, WI.

Harris, R.F. 1980. Effect of water potential on microbial growth and activity. p. 23-95. In L.F. Elliot et al. (ed.) Water potential relations in soil microbiology. SSSA Spec. Publ. 9. SSSA, Madison, WI.

Hovde, C.J., P.R. Aistin, K.A. Cloud, C.J. Williams, and C.W. Hunt. 1999. Effect of cattle diet on Escherichia coli O157:H7 and wild-type Escherichia coli strains. Appl. Environ. Microbiol. 65:3233-3235.

Howell, J.M., M.S. Coyne, and P.L. Cornelius. 1996. Effect of sediment particle size and temperature on fecal bacteria mortality rates and the fecal coliform/fecal streptococci ratio. J. Environ. Qual. 25: $1216-1220$.

Morrison, S.M., and R.L. Martin. 1977. Pathogen survival in soils receiving waste. p. 371-390. In R.C. Loehr (ed.) Proc. 8th Cornell. Agric. Waste Manage. Conf., Cornell Univ., Ithaca, NY. Ann Arbor Sci. Publ., Ann Arbor, MI.

Pyle, B.H., S.C. Broadaway, and G.A. McFeters. 1999. Sensitive detection of Escherichia coli $\mathrm{O} 157: \mathrm{H} 7$ in food and water by immunomag- netic separation and solid-phase laser cytometry. Appl. Environ. Microbiol. 65:1966-1972.

Rawlins, S.L., and G.S. Campbell. 1986. Water potential: Thermocouple psychrometry. p. 597-618. In A. Klute et al. (ed.) Methods of soil analysis. Part 1. Physical and mineralogical properties. Agron. Monogr. 9. 2nd ed. ASA and SSSA, Madison, WI.

Reddy, K.R., R. Khaleel, and M.R. Overcash. 1981. Behavior and transport of microbial pathogens and indicator organisms in soil treated with organic wastes. J. Environ. Qual. 10:255-266.

Rice, E.W., M.J. Allen, D.J. Brenner, and S.C. Edberg. 1991. Assay for $\beta$-glucuronidase in species of the genus Escherichia and its applications for drinking water analysis. Appl. Environ. Microbiol. 57:592-593.

Rice, E.W., M.J. Allen, and S.C. Edberg. 1990. Efficacy of $\beta$-glucuronidase assay for identification of Escherichia coli by the definedsubstrate technology. Appl. Environ. Microbiol. 56:1203-1205.

Rudolfs, W., L.L. Falk, and R.A. Ragotzkie. 1950. Literature review on the occurrence and survival of enteric, pathogenic, and related organisms in soil, water, sewage, and on vegetation. 1. Bacterial and viral diseases. Sewage Ind. Waste 22:1261.

SAS Institute. 1985. SAS user's guide. Statistics. Version 5 ed. SAS Inst., Cary, NC.

Soil Survey Staff. 1992. Procedures for collecting soil samples and methods of analysis for soil survey. USDA-SCS Soil Survey Investigations Rep. no. 1. U.S. Gov. Print. Office, Washington, DC.

Stoddard, C.S., M.S. Coyne, and J.H. Grove. 1998. Fecal bacteria survival and infiltration through a shallow agricultural soil: Timing and tillage effects. J. Environ. Qual. 27:1516-1523.

Tate, R.L. 1978. Cultural and environmental factors affecting the longevity of Escherichia in Histosols. Appl. Environ. Microbiol. 35:925-929.

USDA. 1997. An update: Escherichia coli O157:H7 in humans and cattle. USDA:AHIS:VS Centers for Epidemeology and Animal Health, Fort Collins, CO.

Van Donsel, D.J., E.E. Geldreich, and N.A. Clarke. 1967. Seasonal variation in the survival of indicator bacteria in the soil and their contribution to storm water pollution. Appl. Microbiol. 15: 1361-1370.

Woomer, P.L. 1994. Most probable number counts. p. 59-79. In R.W. Weaver et al. (ed.) Methods of soil analysis. Part 2. Microbiological and biochemical properties. SSSA Book Ser. 5. SSSA, Madison, WI.

Young, C.C., and H. Greenfield. 1923. Observations on the viability of the bact. coli group under natural and artificial conditions. Am. J. Publ. Health 13:270-273.

Zhai, Q., M.S. Coyne, and R.I. Barnhisel. 1995. Mortality rates of fecal bacteria in subsoil amended with poultry manure. Bioresour. Technol. 54:165-169. 